\title{
PEDAGOGICAL PRACTICE - POSITION, CONTRIBUTION AND IMPORTANCE IN THE PROCESS OF PREPARING OF FUTURE TEACHERS
}

\author{
[PEDAGOGICKA PRAX - MIESTO, PRINOS A VYZNAM \\ V PROCESE PRIPRAVY BUDUCICH UCITELOV]
}

\author{
Jan Danek
}

doi: 10.18355/PG.2019.8.1.3

\begin{abstract}
The article deals with the analysis of basic connections of the pedagogical practice as an inevitable part of preparing of future teachers. The evidence is oriented not only to the content side of pedagogical practice and its stages, but to general activities in the area of the organization, personal work and its preparing. In realization of pedagogical practice the students obtain an abundance of impulses not only to the motivation for study, but to persistence or non-persistence in this perspective profession which is as one from the most important professions in the cultural and educational development of every country.
\end{abstract}

\section{Key words}

teacher, students, school, practice, pupils, communication, motivation

Anotácia

V štúdii sú analyzované podstatné súvislosti pedagogickej praxe ako nevyhnutnej súčasti prípravy budúcich učitel'ov. Dôraz je kladený nielen na obsahovú stránku pedagogickej praxe a jej etapy, ale aj na celkovú organizačnú, personálnu i realizačnú prípravu. V jej uplatňovaní získavajú študenti učitel'stva dostatok podnetov nielen pre motiváciu do štúdia, ale v oblasti zotrvania, či nezotrvania v tomto perspektívnom povolaní, ktoré sa javí ako jedno z najdôležitejších pri kultúrnom a vzdelanostnom rozvoji každej krajiny.

\section{Kl’účové slová}

Učitel', študenti, škola, prax, žiaci, komunikácia, motivácia

\section{Úvod}

Prax robí majstra, to je dávna odborná i spoločenská múdrost’ v orientácii na výkon akejkol'vek pracovnej činnosti. Praxou získava každá odborníčka, či odborník stále výraznejšie zručnosti a návyky spojené s nevyhnutnost'ou inovatívnych vedomostí a preto je nevyhnutná výrazná úcta voči každému majstrovi svojho remesla, ktorý dokáže vlastnou činnost'ou aktivizovat' aj svoje okolie. Inak tomu nemôže byt' ani v prostredí výchovy a vzdelávania, teda v školách, kde prax nielenže rozvíja pedagogické majstrovstvo učitel'ky či učitel'a, ale rozvíja aj záujem detí a mladých l'udí o vzdelávanie a kultúrne správanie. Zároveň však prax aj u mladších adeptov učitel'skej činnosti 
pôsobí nielen na kvalitu ich celkovej práce, ale výrazne aj ovplyvňuje vzt’ah $\mathrm{k}$ budúcemu povolaniu a všetkým aspektom jeho výkonu. Lebo práve vzt’ah k učitel'skému povolaniu výrazne ovplyvňuje všetky aspekty jeho výkonu zdokonal'ovanie sa $\mathrm{v}$ špecializáciách, pedagogicko-psychologickej kvalite, osobnostnému rastu, uvedomovaniu si sily a významu vlastnej profesie. Túto skutočnost' je potrebné zachytit' už v procese prípravy budúcich učitel'ov, lebo ,povaha učitel’skej práce viac zodpovedá holistický prístup, v ktorom je kvalita učitel’a chápaná ako komplexná charakteristika zahŕnajúca mnoho vzájomne previazaných aspektov a dimenzií (aj t’ažko meratel'ných, či dokonca pozorovatel'ných). Reflexia praxe tu vystupuje ako integrujúci faktor medzi vedomost'ami učitel'a a schopnost'ou uplatnit' ich v edukačnej realite, medzi rôznymi aspektmi jeho práce, medzi minulou, terajšou a budúcou kvalitou jeho práce“ (Kosová, Tomengová a kol., 2015, s.20). Prax zároveň slúži aj ako overovanie, či uplatňovanie, všetkých poznatkov a schopností učitel'ky či učitel'a z didaktiky, teórie výchovy, sociálnej pedagogiky a radu d’alších pedagogických disciplín. Nehovoriac už o vlastnej sebareflexii vo vzt'ahu k povolaniu, záujmu vykonávat' ho a vidiet' v ňom profesionálnu alebo osobnú perspektívu. Všetky uvedené aspekty má v prvotnej motivácii realizovat' práve učitel'skú prax ako organizačnú súčast' a disciplíny vyučovania umožňujúce vstúpit do všetkých súvislostí výchovno-vzdelávacej činnosti a vidiet' ju z iného pohl'adu ako bol pohl'ad, či skúsenost' v pozícii žiaka základnej alebo strednej školy.

Pedagogická prax sa v tomto zmysle predstavuje ako „integrujúca súčast' prípravy poslucháčov učitel'ského štúdia, v ktorej sa prelínajú všetky jej zložky. Ciel'om pedagogickej praxe je príprava budúcich učitel'ov na vyučovanie a výchovnú prácu $\mathrm{s}$ det'mi a mládežou $\mathrm{v}$ školách a školských výchovno-vzdelávacích zariadeniach. Pedagogická prax sa realizuje podl'a učebných plánov formou úvodnej, priebežnej a súvislej pedagogickej praxe "( Pedagogická encyklopédia Slovenska, 2, P-Ž, 1985, s.33). Autorky a autori publikácie Profesijná praktická príprava budúcich učitel’ov (Kosová, Tomengová a kol., 2015, s. 46 ) v tomto zmysle nadväzujú na uvedené poznanie konštatovaním, že "príprava študentov učitel'stva na vyučovanie a každodenný život školy prostredníctvom praktického tréningu, t. j. praktického vyskúšania si stratégií, metód, techník vyučovania, riadenia triedy, práce so žiakmi a rôznych d’alších aktivít súvisiacich s učitel'skou profesiou, ktorá sa realizuje $\mathrm{v}$ podmienkach škôl a učitel'ských fakúlt. Je interakciou medzi naučenou teóriou a jej aplikovaním $\mathrm{v}$ školskej praxi a umožňuje študentom učitel'stva reálnu akciu a jej reflexiu." Pedagogická prax sa stáva, $\mathrm{s}$ určitými problémami, organickou súčast’ou prípravy budúcich učitel'ov s ciel'om získania a dosiahnutia úspešnosti v identifikácii možností žiakov a tried, sledovat' realizáciu vzdelávania a výchovného pôsobenia, vediet' realizovat' vyučovanie a výchovu, vytvárat' klímu pre vyučovanie $\mathrm{v}$ škole a atmosféru $\mathrm{v}$ triede, hodnotit' prácu žiakov a realizovat' sebareflexiu v orientácii učitel'skú prácu. Pedagogickú prax je potrebné viazat' aj na fakty motivácie pre výber učitel'ského povolania, čo môže jej realizácia podporit' alebo eliminovat'. Predovšetkým sa ale vyžaduje kvalitné zabezpečenie a organizácia praxe, ktorá má študentovi učitel'stva výrazne sprístupnit' nielen vzdelávaciu, vyučovaciu činnost' ale aj výchovné pôsobenie, celkovú 
organizačnú, administratívnu a d'alšiu študijnú činnost' v zmysle prehlbovania motivácie a záujmu o výkon učitel'ského povolania. Prax v školách, a predovšetkým učitel'ských fakultách, teda fakultách, kde sú budúci učitelia pripravovaní, dokazujú, že študenti aj počas štúdia výrazne zápasia s myšlienkou ich vzt'ahu nielen k učitel'skému štúdiu, ale aj k práci učitel'a, k čomu majú prispiet' jednotlivé vyučovacie disciplíny ako je všeobecná pedagogika, teória výchovy, všeobecná, odborová i predmetová didaktika, dejiny pedagogiky, sociálna pedagogika, špeciálna pedagogika, pedagogická psychológia a rad d’alších, ktoré majú budúcemu adeptovi učitel'stva jednoznačne ukázat', že pre neho nie sú prvoradé len vyučovacie predmety jeho konkrétnych špecializácií , ale aj pedagogické, psychologické, filozofické a d’alšie disciplíny učebného plánu vysokoškolského štúdia v študijnom odbore a programe. Konštatovanie znamenajúce skutočnost', že študent učitel'stva nebude len slovenčinár, dejepisár, matematikár, prírodopisár, telocvikár a pod., ale predovšetkým učitel' v súhrnnej profesii, na čo sa často zabúda. V procese vysokoškolskej prípravy, a najmä pedagogickej praxe, je nutné študentom sprístupňovat' poznanie, že ako skutoční odborníci sa musia prejavit' výraznou odbornost'ou a vzdelanost'ou v oblasti štúdia. Práve tieto odborné kvality, všeobecne charakterizujúce učitel'a, boli a sú podstatným motívom pre učitel'ské štúdium, lebo učitel' je v súhrne vysokokvalifikovaný vedec v špecializáciách vyučovania, v pedagogicko-psychologických zameraniach, vynikajúci rečník a dynamická osobnost'. Osobnost' v očiach širokej verejnosti, žiakov a ich rodičov. Ale nie je možné vymedzit' len osobnostné prejavy konkrétneho jednotlivca v komunikácii, angažovanosti, všeobecnej spoločenskej vyrovnanosti, kooperatívnosti, celkovej hodnotovej orientácie či svetonázoru. Celkový vzt'ah a analýza učitel'skej práce jasne naznačujú, že povolanie učitel'a je zložité, náročné a najmä vysoko zodpovedné voči det'om a mladým l'ud'om v základných a v stredných školách. V určitých vývinových situáciách aj na vysokých školách. A štúdium učitel'stva je skutočne výrazne náročné, komplikované a odborne rozsiahle. S pedagogickou praxou je bezprostredne spojená aj autorita učitel'ského povolania v spoločnosti, v ktorej je síce výrazne deklarovaná, ale reálne málo finančne, spoločensky i politicky podporovaná, čo sa prejavuje v mnohých prov v správaní sa žiakoch rodičov, ale aj zriad'ovatel'ov škôl.

Aj napriek skutočnosti nevyhnutného vzdelávania a výchovy všeobecne, ale aj prípravy konkrétnych odborníkov pre národné hospodárstvo. Súčasná spoločnosti, v zmysle jej celkovej sociálnej i hodnotovej orientácie, ale aj úrovne kultúry a perspektív nevyhnutne potrebuje kvalitných remeselníkov rozličných odborov, organizačných pracovníkov, technicko-hospodárskych odborníkov a z oblasti vysokoškolského vzdelávania kvalitných informatikov, učitel'ov a strojárov, ale aj lekárov, ktorí ale , v zmysle Hyppokratovej prísahy, slúžia predovšetkým domácemu obyvatel'stvu. Skutočnosti, ktoré sú spojené s celkovým spoločenským, ale aj hospodárskym rozvojom a spoločenskou orientáciou v podmienkach učiacej sa, vedomostnej spoločnosti. V tomto smere je nevyhnutné obracat' sa k skúsenostiam a podmienkam iných krajín, v ktorých je učitel'ské povolanie vysoko oceňované, spoločensky vážené a medzil'udsky vysoko uznávané. 
Ako napríklad v Nemecku, Singapúre, Japonsku, Kórejskej republike, Švédsku, Fínsku a d’alších krajinách. Ale aj v nadväznosti na historické tradície a prístupy $v$ minulosti našich krajín, najmä Československej republiky, ked' $\mathrm{v}$ tridsiatych rokoch 20.storočia, období pozície krajiny ako desiatej najvyspelejšej krajiny vtedajšieho sveta, boli práve učitelia, spolu s právnikmi a lekármi najvýraznejšie uznávanými a podporovanými povolaniami. Uvedená skutočnost' je podnetom pre hodnotenie učitel'ského povolania aj $\mathrm{v}$ súčasnosti, ked' vinou rozličných omylov a chýb v riadení spoločnosti sa učitel'stvo dostalo do závozu s vplyvom na morálku, kultúru, l'udské vzt’ahy i hodnotovú orientáciu spoločnosti. Príčinou sú stále dôsledky netransparentnej privatizácie, neohraničenie verejnej činnosti vzdelaním, výrazná glorifikácia niektorých osôb, jednostranné vysvetl'ovanie spoločenských javov v minulosti a súčasnosti a pod. Potreba dynamizácie výchovy a vzdelávania $\mathrm{v}$ orientácii na celkovú hodnotovú orientáciu, medzilludské vzt’ahy, kultúrnu úroveň so základom v dodržiavaní a presadzovaní hodnôt občianskej spoločnosti, lebo stavovská spoločnost' už patrí, v zmysle dejinného vývoja, minulosti. Dodržiavanie a riadenie sa týmito hodnotami je výrazne viazané práve na výchovu a vzdelávanie pri rešpektovaní a uznávaní spoločenskej potreby učitel'skej práce a učitel’ov vôbec ako vysokoškolsky vzdelaných, kvalifikovaných odborníkov pre procesy výchovy a vzdelávania ( Danek, 2018 ), ktorí v det’och a mladých l'ud'och nielenže objavujú ich schopnosti, talenty a možnosti, ale ich vlastnou výchovnou a vzdelávacou aktivitou a pôsobením aj rozvíjajú, prípadne negatívne prejavy eliminujú. Teda pôsobia na podstatné vlastnosti osobnosti každého jednotlivého žiaka, ktorými sú charakter, talent, temperament, záujmy či schopnosti v zmysle rozvoja, predovšetkým, kultivovanej osobnosti s ciel'om menej konformných a rudimentárnych osobností (Kováč, 2010 ). Všetko sú to výsledky súvislostí podmienok kultúry a hospodárstva krajiny, ktoré musia klást' dôraz na človeka- občana ako podstatnú hodnotu spoločnosti a jej celkového života, tvorcu a užívatel'a všetkých vytvorených duchovných i materiálnych hodnôt s prínosom do ich rozširovania a odstraňovania príživníctva, zneužívania možností sociálneho zabezpečenia a hlavne nehospodárneho narábania s verejnými prostriedkami.

Všetko sú to normy, ku ktorým má dospievajúcich, v základoch i v neskorších obdobiach, viest' a usmerňovat' práve výchovná a vzdelávacia práca učitel'ov. Faktory celkového zamerania práce a hlavne prípravy budúcich učitel’ov, na uznaní práce ktorých, a ich výsledkov, je závislá ekonomická prosperita, ale aj morálna i kultúrna úroveň spoločnosti. Preto je tomuto povolaniu potrebné venovat' maximálnu spoločenskú pozornost' $\mathrm{v}$ príprave i podmienkach práce, vrátane vplyvu pedagogickej praxe ako jej organickej súčasti. Najefektívnejšia príprava vysokoškolsky vzdelaných odborníkov je vtedy, ak sa výrazne široká škála všeobecných i odborných poznatkov spája s realitou praxe $\mathrm{z}$ dôvodov ju nielen dobre poznat', ale na základe vzdelania ju aj progresívne pretvárat'. Pripravenost', na základe ktorej odborníci, vstupujúci do praktického výkonu povolania prejavujú vel'ký rozhl'ad, dynamiku poznania, široké odborné vedomosti podporujúce samostatné myslenie a rozhodovanie s dôrazným poznaním praxe a výraznými praktickými zručnostami a návykmi. Pripravenost', ktorá je 
možná v procese štúdia len $\mathrm{v}$ aplikácii a spojení s podmienkami reality. Súvislosti, ktoré podmieňujú kvalitu a efektívnost', produktívnost' a úspešnost' akéhokol'vek povolania. Pedagogická prax má byt' v učitel'skej príprave chápaná ako organická a neoddelitel’ná súčast' študijného plánu na každej vysokej škole, ktorá budúcich učitel'ov pripravuje. V praxi to znamená vstup do uplatňovania pedagogickej komunikácie, používania učebných názorných pomôcok, vhodné zarad'ovanie informačno-komunikačných technológií (napr. počítačov či interaktívnych tabúl' ), riešenie situácií, uplatňovanie zážitkového vzdelávania a výchovy, budovanie vzorov a pod. Ale zároveň aj uvedomovanie si prínosu a významu školy pre každého jednotlivca a konkrétneho učitel'a vo vzt’ahu $\mathrm{k}$ určitému vyučovaciemu predmetu, či záujmovej činnosti. Na tieto všetky tieto skúsenosti a podnety nadväzuje, $\mathrm{v}$ súlade so získanými poznatkami a vedomostami, práve pedagogická prax vo fázach sledovania práce cvičných učitel'ov, potom vlastnej pedagogickej činnosti pod dozorom a usmerňovaním skúseného pedagóga a potom súvislá pedagogická prax $\mathrm{v}$ škole s priestorom pre samostatnú výchovnú a vzdelávaciu činnost', samozrejme, že pod kuratelou cvičného učitel'a. Pri plánovaní a realizácii pedagogickej praxe je potrebné počítat nielen s odbornými faktami tohto procesu, ale aj motivačnými a procesuálnymi postupmi, čo znamená spojenie rozumového, racionálneho a emocionálneho faktu s poznaním skutočnej podstaty učitel'skej činnosti vo všetkých oblastiach. Je to skutočnost' motivácie nielen pri rozvíjaní odbornosti v oblasti špecializácií, pedagogicko-psychologického prístupu $\mathrm{k}$ det’om a mládeži, ale zároveň aj k vlastnému osobnostnému rastu . Zároveň je tu nevyhnutnost' zoznámenia sa s celkovým obsahom a dynamikou pracovného dňa učitel'a nielen $\mathrm{v}$ školských podmienkach, ale aj v mimoškolskom prostredí obce. Pedagogická umožňuje priamy vstup do školského prostredia a v súlade so študovanou teóriou umožňuje poznávanie reality.

Preto prepojenost' škôl a pedagogickej praxe je nevyhnutná a podstatná, lebo vzniká vzt’ah nielen medzi fakultou, ktorá pripravuje budúcich učitel'ov, ale aj medi školami a študentami. Presne tak, ako vzniká vzt’ah medzi budúcim výkonným pracovníkom (remeselníkom, manažérom a pod.) a firmou či pracoviskom. Pre pedagogickú prax podmienky a realizáciu jej výkonu podnecuje zákon o výchove a vzdelávaní č. 245 / 2008 Z.z., v zmysle ktorého majú byt' ustanovené cvičné školy, ale existuje stále vážny problém pôsobiaci na zat’aženie cvičných učitel’ov, zasahovanie do procesov výchovy a vzdelávania, zodpovednost' za žiakov, kvalita výchovy a vzdelávania, či iné súvislosti. Škola, ktorá pracuje s budúcimi učitel'mi má výrazný podiel na kvalite učitel'skej prípravy, lebo, $\mathrm{v}$ spolupráci $\mathrm{s}$ fakultou pripravujúcou učitel’ov, zabezpečuje nasledujúce úlohy:

1.bezprostredný kontakt študentov s realitou výchovy a vzdelávania,

2.podporu budúcim učitel'om zo strany skúsenejších kolegov,

3.spoznávanie skutočného zmyslu a poslania učitel'skej profesie,

4.uvedomenie si prepojenosti učitel'skej špecializácie cez vyučovacie predmety a všeobecné fakty, úlohy a potreby výchovy a vzdelávania,

5.rozvoj komunikačných schopností a reakcií v podmienkach školskej reality, 
6.dôveru v seba samého a kolektív,

7.motiváciu k d'alšiemu štúdiu a sebazdokonal'ovaniu,

8.sebahodnotenie vo vzt'ahu k rodičom a zákonným zástupcom detí,

9.konkrétne návyky spojené so štýlom práce školy v zmysle jej úloh a poslania,

10.poznanie významu riadenia školy z hl'adiska všetkých aktérov školy.

V podmienkach realizácie pedagogickej praxe $\mathrm{v}$ škole sa prepája teória s praxou a prechodom do skutočnej reality $\mathrm{v}$ zmysle postupnosti a nadväznosti jednotlivých učitel'ských aktivít. Či je to prvý kontakt študentov učitel'stva s celkovou klímou školy či atmosférou v triedach. $\mathrm{V}$ tomto zmysle „ciel'om pedagogickej praxe je získat' profesijné kompetencie pre výkon povolania prepojením praktických skúseností s teoretickými vedomost'ami a to najmä vediet' identifikovat' individuálne charakteristiky žiakov a skupinové charakteristiky tried vediet' projektovat' a realizovat' vyučovanie a učenie sa, vediet' hodnotit' vyučovanie, procesy učenia sa a učebné výsledky žiakov, vediet' využívat' spätnú väzbu a sebareflexiu na rozvíjanie učitel'ských spôsobilostí“" (Kosová, Tomengová a kol., 2015, s. 47). S týmito skutočnost'ami samozrejme súvisí aj výchovné pôsobenie, ktoré je v procese prípravy budúcich učitel'ov na fakultách vysokých škôl, ale i v procese pedagogickej praxe v určitej miere zanedbávané. Teória výchovy má síce v učebnom pláne učitel'stva svoje nezastupitel'né miesto, ale prax stále kladie dôraz na vzdelávanie, vyučovanie a zdôrazňovanie všeobecnej, odborovej, či predmetovej didaktiky . Realizácia pedagogickej praxe zároveň študentovi - praktikantovi umožňuje „,- implementovat' teoretické poznatky v konkrétnej realizácii vyučovacieho procesu, - rozvíjat' pedagogické myslenie, - ozrejmit' pedagogickú a psychologickú teóriu a teóriu vedného odboru príslušného aprobačného predmetu, - rozvíjat' si potrebné pedagogické schopnosti a zručnosti pod odborným vedením cvičného učitel'a, - učit' sa prostredníctvom aktívnej činnosti a konania $\mathrm{v}$ prirodzenom školskom prostredí, - spoznávat' realitu školskej praxe a súvislostí, ktoré ju ovplyvňujú, rozvíjat' si profesijné i osobnostné kompetencie nevyhnutné pre aktívny osobný i pracovný život, rozvíjat' pozitívny vzt'ah k svojmu vysokoškolskému štúdiu a učitel'skému povolaniu, - získat' spätnú väzbu o svojom doterajšom vzdelávaní, - kreovat' morálne postoje k žiakom, kolegom, rodičom a k spoločnosti “ (Sirotová, 2015, s.80-81).

V tomto zmysle majú teda výrazný podiel a úlohu práce cviční učitelia, od ktorých práce kvalita jej realizácie vel'mi závisí v zmysle poznania, že prax robí majstrov. Je len samozrejmé, že pri všetkej kvalitnej organizačnej príprave, ale aj pri obsahovom stvárnení pedagogickej komunikácie vel'a záleží práve na cvičných učitel'och. Cviční učitelia na budúcich adeptov učitel'skej práce vplývajú a výrazne ich ovplyvňujú jednak vlastným prístupom k nim, celkovou charakteristikou a vzt'ahom k vlastnej práci, úctou a rešpektom voči svojmu povolaniu $\mathrm{z}$ hl'adiska prezentácie jeho významu, ocenenia i perspektív a zároveň aj celkovou vážnost’ou voči pozícii cvičného učitel'a. Aj v tomto prípade výrazne platí poznanie, prínosu a vplyvu vzoru pre d'alšiu činnost' a správanie sa v existujúcom prostredí. Cvičný učitel' 
práve jeden z faktorov ktorý ovplyvňuje profesionálnu i spoločenskú perspektívu študentov učitel'stva. Znamená to súhrn faktorov, ktoré pôsobia na prácu, štúdium a budúce pôsobenie študenta $\mathrm{v}$ študijnom odbore. Je to motivácia vol'by na príklade učitel'a základnej či strednej školy, spôsob, prístup a vzt'ah k študentom zo strany vysokoškolských učitel'ov na jednotlivých katedrách fakúlt vysokých škôl pripravujúcich učitel'ov, spoločenská klíma vo vzt’ahu k významu učitel'ského povolania, organizácia pedagogickej praxe na príslušnej fakulte a vnímanie praxujúcich študentov v podmienkach konkrétnych škôl. Teória a prax prípravy budúcich učitel'ov jednoznačne dokazuje, že práve podmienky škôl výrazne ovplyvňujú vzt'ah $\mathrm{k}$ budúcemu povolaniu. $\mathrm{V}$ tejto súvislosti nemožno uvažovat' o nedocenení významu učitel'skej práce, má výraznú pozíciu a vplyv, ale podstata je v reálnom prístupe k celkovej učitel'skej práce, jej vzdelávacieho, výchovného a medzil'udského naplňovania. Cvičný učitel' môže v tomto zmysle výrazne ovplyvňovat' d'alšie uvažovanie praktizujúceho študenta jednak postojom, názormi, vysvetlovaním, organizáciou a príkladmi z vlastnej praktickej činnosti. Pedagogická prax v konkrétnych etapách nie je len o podmienkach škôl, ale aj o celkovej spoločenskej situácii v zameraní v zameraní na autoritu vzdelania a slušnosti v existujúcich podmienkach. V praxi budúcich adeptov učitel'stva je nutné strany cvičných učitel'ov, či už na základe ich presvedčenia alebo len vzt'ahu, vysvetl'ovat' význam vzdelania a vzdelanosti v zmysle možnosti prístupu k poznaniu všetkých poznaní, ktoré l'udstvo doteraz dosiahlo, lepšej ochrany životného prostredia, lepšej pracovnej výkonnosti a spoločenskej pozície, lepšej ochrany zdravia, vlastnej i kolektívnej bezpečnosti, spoločenskej aktivity, kultúrnosti komunikácie, či dôstojnosti človeka (Our Creative Diversity, 1995). Skutočnosti, ktoré majú takisto ovplyvňovat' vzt'ah k učitel'skému povolaniu a utváraniu hrdosti na vlastné budúce poslanie. Každé povolanie vyžaduje po skončení prípravy k jeho výkonu určité praktické skúsenosti, či vyžaduje stredoškolské alebo vysokoškolské vzdelanie, lebo umožňujú plynule realizovat' stanovenú prácu. Pri praxi budúcich učitel'ov je potrebné zdôrazňovat' aj iné spoločenské súvislosti, hlavne $\mathrm{v}$ smere perspektív povolania. Ministerstvo práce, sociálnych vecí a rodiny Slovenskej republiky vyjadrilo poznanie, že z hl'adiska uplatnenia sa v praxi a potreby národného hospodárstva majú najvýraznejšiu perspektívu tri povolania s vysokoškolským vzdelaním a to informatici, učitelia a strojári, čo je bezprostredne spojené s líniou rozvoja výroby, spoločnosti a celkového osobnostného rozvoja občanov. Z hl'adiska praxe je v učitel'skej príprave nutné uvažovat' aj o jej realizácii, čo znamená zabezpečenie spolupracujúcich škôl, cvičných škôl alebo priamo fakultných škôl, kde by mohli pôsobit' aj učitelia fakúlt a skúsení pedagógovia škôl by mohli realizovat' vyučovanie študentov, napríklad v oblasti všeobecnej, odborovej a predmetovej didaktiky. Lebo didaktická príprava budúcich učitel'ov zo strany vysokoškolských učitel'ov v kariérnom postupe študent magisterského štúdia, študent doktorandského štúdia a vysokoškolský učitel' nemá tú požadovanú kvalitu. Podobne nereálne by bolo napr. na lekárskych fakultách, kde by chirurgiu vyučoval pedagóg, ktorý nikdy neoperoval. Preto je potrebné uvažovat', na základe domácich i zahraničných skúseností napr. 
o centrách pedagogickej praxe, ktoré by tieto podmienky zabezpečovali. „, Preto pre účelnost' (produktivitu) pedagogickej praxe má vel'ký význam analýza systému profesných klúčových kompetencií učitel'a a na základe tejto analýzy stanovenie etáp postupného získavania týchto učitel'ských kompetencií $\mathrm{v}$ praktickej príprave, pri realizácii jednotlivých druhov pedagogickej praxe, $\mathrm{v}$ súlade $\mathrm{s}$ už zvládnutými teoretickými čast’ami pregraduálnej prípravy učitel’a “(Št’áva, 2005, 12). Je preto nevyhnutné , aby v procese pregraduálnej prípravy, počas prednášok, seminárov a cvičení spojenými s narábaním s poznatkami z jednotlivých disciplín, pracovalo so skúsenostami a potrebami praxe, aby téma praktickej aplikácie bola organickou súčast'ou práce nielen študentov, ale aj vysokoškolských pedagógov. Tým sa pedagogická prax stane výraznejšou súčast'ou celkovej učitel'skej prípravy v plynulom rozvíjaní osobnosti budúceho učitel'a, lebo prax je viazaná na celkový osobnostný vývoj učitela, ktorý začína počiatočnou motiváciou $\mathrm{v}$ podmienkach strednej školy, pokračuje prípravou v podmienkach vysokoškolského štúdia s poznávaním súvislostí učitel'skej činnosti nielen teoreticky, ale aj prakticky a začínajúcou učitel'skou aktivitou v školskom prostredí. Zároveň, v súvislosti poznania všetkých kompetencií učitel'a, od vyučovania, vzdelávania, vlastného štúdia, výchovy, organizácie práce detí, ich ochranou, kontaktom a spoluprácou s rodičmi detí je potrebné si uvedomit' aj fakt, že učitel' je celou svojou činnost'ou a pôsobením verejný činitel'. Kompetencie učitel'ov sú širokospektrálne a v súvislosti s ich prípravou na povolanie, prostredníctvom teórie a praxe, je nutné d’alej pracovat' s poznaním, že učitel'ka alebo učitel' sú vysokoškolsky vzdelaní odborníci pre procesy výchovy a vzdelávania, čo je vel’mi výrazná nielen odborná, ale aj celospoločenská úloha. Učitel'ka, či učitel' svojou prácou a pôsobením v oblasti vyučovania, širšieho vzdelávania, výchovy, diagnostiky či poradenskej činnosti nielenže u detí a mladých l'udí spoznáva ich predpoklady, schopnosti či problémy, ale ich svojím prístupom a celkovou činnostou aj rozvíja alebo utlmuje, prípadne odstraňuje. Zároveň nie je možné zabúdat' ani na skutočnost', že učitel'ka, či učitel' musí byt', v nadväznosti na celkové plnenie vlastných úloh vzdelávaní, výchove, vytváraní pracovnej i emocionálnej klímy $\mathrm{v}$ školách a triedach, dobrá rečníčka a dobrý rečník pozitívnym vplyvom na celkovú emocionálnu i životnú orientáciu detí a mladých l’udí vo vztahu ku škole. V tomto zmysle je nutné vidiet' všetky súvislosti a podmienky prípravy pre výkon učitel'ského povolania, ktorých kvalitu môže výrazne ovplyvnit' práve pedagogická prax. Lebo "spôsobnosti, potrebné pre fundovaný osobný rozvoj budúcich učitel'ov sú podmienené kvalitnými vedomost’ami, uvedomeným, aktívnym prístupom $\mathrm{k}$ ich nácviku $\mathrm{v}$ modeloch a skutočných situáciách $\mathrm{s}$ kritickou reflexiou“ (Doušková, 2005, s. 40). Fakt, ktorý je spojený aj virtuálnou realitou, čo znamená predstavy analýzy a d’alšie súvislosti hodnotenia prípravy budúcich učitel'ov. Potrebné zdôrazňovat' skutočnost', aby všetky aktivity boli $\mathrm{v}$ štúdiu premieňané do faktov reality, čo znamená prepojenie poznatkov, aktivít, rozborov na realitu skutočnosti s uvedomovaním si skutočnosti prípravy budúcich učitel'ov pre život a prácu $\mathrm{s}$ cítiacimi, pracujúcimi a učiacimi sa det’mi. Je to proces nielen prípravy pre realizáciu výchovy a vzdelávania, ale aj na vstupovanie do reality výchovno- 
vzdelávacej sústavy, reality poznania významu vzdelania, okruhov riadenia škôl a školských zariadení, miery zodpovednosti škôl za ich činnost' v zmysle akontability, doceňovania vzdelania a poznania nadväznosti jednotlivých stupňov, druhov a typov škôl. Lebo nie je možné výrazne pozitívne motivovat' $\mathrm{k}$ vzdelávaniu $\mathrm{v}$ prípade, ak je nedostatočne ocenené a vážené, nie je možné efektívne a úspešne vychovávat' $v$ podmienkach nerešpektovania nielen slušnosti a zákonnosti v krajine, nie je možné zdôrazňovat' právo a spravodlivost' bez ich reálneho spoločenského základu, vytvárat' reálne medzil'udské vzt'ahy bez kultúrnej komunikácie, utvárat pozitívny vzt’ah $\mathrm{k}$ spoločnosti pri jej nejasnom riadení, nemožno hovorit' o rovnosti a dôstojnosti v podmienkach uplatňovania stavovského prístupu, nemožno učit' ekonomicky a ekologicky mysliet' pri nehospodárnom narábaní s verejnými prostriedkami a pod. (Danek, 2018). Preto, pri úspešnej príprave budúcich učitel'ov, nie je možné len dodržiavat' podstatu pedagogických, psychologických alebo spoločenských faktov a poznatkov, ale aktívne vstupovat' aj do celkovej spoločenskej situácie, vzt'ahov, problémov, pozície človeka v spoločnosti a pod. Je to príprava zážitkom znamenajúcim priamy kontakt so svetom, so sebou samým, so životom s dôsledkom zmien v správaní, komunikácii, vyjadrovaní názorov a zaujímania stanovísk. Nesprávne sú teda názory, uvádzajúce a zdôrazňujúce len odborný prístup pedagogiky a psychológie, bez poznania celkovej spoločenskej situácie, lebo je potrebné si uvedomovat' skutočnost', že osobnost' človeka znamená integrovanú jednotu vnútorných predpokladov a vonkajších vplyvov, čo sa prejavuje v celkovej činnosti každého človeka (Kováč, 2010). V tomto zmysle je nutné pripravovat' aj budúcich učitel'ov aj preto, lebo budú pracovat' so živými, dynamickými, hladajúcimi a poznávajúcimi l'udskými bytostami, utvárajúcimi sa osobnostami v zmysle ich svojbytnosti, identity, socializovanosti a samostatnosti $\mathrm{v}$ súlade $\mathrm{s}$ nevyhnutnost'ou dôstojnosti a zodpovednosti každého jednotlivca. Pedagogická prax preto, v nadväznosti na teoretické a praktické približovanie a zoznamovanie sa s jednotlivými oblast’ami práce učitel'a, umožňuje adeptom tohto povolania a životného poslania spoznávat' a identifikovat' sa s jeho skutočnou realitou. Nielenže v zmysle jeho obsahu a pôsobenia učitel'a v smere odbornosti voblasti vyučovacích predmetov, pedagogicko-psychologických schopností a osobnostných prejavov, ale aj s poznaním a uznávaním významu a prínosu odborných, technických či administratívnych zamestnancov škôl pre úspešnost' výchovy a vzdelávania $\mathrm{v}$ škole a $\mathrm{s}$ nimi spojeného celkového osobnostného rozvoja každého diet’at’a či dospievajúceho. Konštatovanie, ktoré je podporené aj d'alším názorom, že „ciel’om pedagogickej praxe je rozvoj osobnosti vysokoškolského študenta - praktikanta do takej miery, aby bol schopný po absolvovaní štúdia začat' vykonávat' povolanie učitela. Pedagogická prax je procesom, ktorý zabezpečuje rozvoj nielen profesijných kompetencií, ale aj osobnostných kompetencií. Povolanie učitel’a nie je možné odosobnit', učitel' vplýva na svojich žiakov celou svojou osobnost'ou a preto je nevyhnutné, aby pedagogická prax rozvíjala osobnost' študenta komplexne" (Sirotová, 2015, s.80). A s tým zasahuje aj do rozvoja kvality a humanizácie prostredia, spoločnosti, morálky a všetkých noriem života patriacich do všel'udských hodnôt. Vychádzajúc z týchto faktov potom " 
pedagogická prax má plnit' tri dôležité úlohy. A to je poznávanie školy zo strany študentov učitel'stva, zbavovat' študentov obáv a trémy z komunikácie so žiak a získané poznatky, štúdiom na fakulte, konfrontovat' s realitou školského života“ (Danek, 2005, s.77). V tomto zmysle pedagogická prax v školách neznamená len d’alší rozvoj celkovej odbornosti konkrétneho študenta, ale aj upevnenie, či oslabenie motivácie pre výkon tak spoločensky dôležitého povolania.

Štúdia bola spracovaná ako súčast' riešenia vedecko-výskumného projektu KEGA - 015UCM - 4/2018 „Pedagogická prax vysokoškolských študentov s podporou virtuálnej dimenzie.“

\section{Bibliographic references}

BAITON, R.H. 2017. Luther. Zivot a dielo reformatora. Bratislava: Porta Libri. ISBN 978-80-8156-080-4.

DANEK, J. 2018. Osobnost, spolocnost, vychova. Nadlak: Vydavatelstvo Editura - Ivan Krasko. ISBN 978-973-107-127-5.

DANEK, J. 2011. Uvod do filozofie vychovy. Praha: UJAK. ISBN 978-807452-011-2.

DANEK, J. 2005. Pedagogicka prax - neoddelitelna sucast pripravy buducich ucitelov. In. Janik, T., Havlik, J. (eds.). 2005. Pedagogicka praxe a profesni rozvoj studentu. Brno: MU. ISBN 80-210-3884-5.

DOUSKOVA, A. 2005. Obsahova analyza projektov vyucby z odbornej pedagogickej praxe - vztah ucebny ciel - ucebne ulohy. In. Janik, T., Havlik, J.(eds.). Pedagogicka praxe a profesni rozvoj studentu. Brno: MU. ISBN 80210-3884-5.

DOUSKOVA, A. - LUPTAKOVA, K. (eds.). 2007. Ucitelske kompetencie a pedagogicka prax. Banska Bystrica: UMB. ISBN 978-80-8083-437-1.

DOUSKOVA, A. - LUPTAKOVA - VANCIKOVA, K. (eds.). 2009. Reflexia a sebareflexia ako nastroj skvalitnenia pedagogickej praxe. Banska Bystrica: UMB. ISBN 978-80-8083-897-3.

KOSOVA, B., TOMENGOVA, A. a kol. 2015. Profesijna a prakticka priprava buducich ucitelov. Banska Bystrica: Belianum. ISBN 978-80-5570860-7.

KOVAC, D. 2010. Osobnost, jej utvaranie a sebautvaranie. Bratislava: SAV. ISBN 978-80-88910-31-2.

Our Creative Diversity. 1995. Paris: UNESCO.

Pedagogicka encyklopedia Slovenska, 2, P-Z. 1985. Bratislava: Veda.

SIROTOVA, M.2015. Pedagogicka prax v pregradualnej priprave ucitelov. Trnava: UCM. ISBN 978-80-8105-648-2.

STAVA, J. 2005. Intervence do procesu rozvijeni pedagogickych dovednosti studentu ucitelstvi 2. stupne zakladni skoly a ucitelstvi pro stredni skoly v prubehu jejich praxe na fakultni skole. In. Janik, T., Havlik, J. (eds.). Pedagogicka praxe a profesni rozvoj studentu. Brno: MU. ISBN 80-2103884-5. 
prof. PaedDr. Ján Danek, CSc.

Department of Pedagogy

FF UCM

University of SS. Cyril and Methodius in Trnava

Nám. J. Herdu 2

91701 Trnava

Slovakia

jan.danek@ucm.sk 